\title{
Summer Solar Radiation in the Canadian High Arctic
}

\author{
MING-KO WOO ${ }^{1}$ and KATHY L. YOUNG ${ }^{2}$
}

(Received 17 April 1995; accepted in revised form 15 February 1995)

\begin{abstract}
The limited number of weather stations in the Canadian Arctic Islands has prevented the mapping of incoming shortwave radiation. A cloud layer model, using cloud observations reported by summer field camps supported by the Polar Continental Shelf Project, allows the computation of solar radiation for these widely scattered arctic sites. The calculated values were combined with the measured data from the weather stations to examine the temporal and spatial variations of summer radiation. For the years studied (1974-93), incoming shortwave radiation was the highest in June and declined afterwards. On a local scale, coastal low clouds that are prevalent during the open-water periods reduce the solar radiation receipt, but local variability is unlikely to mask the regional trends. At a regional level, most field camps are highly correlated with their closest weather stations. The short-term field camp data were adjusted with the long-term means of the weather stations to map the distribution of solar radiation for the months of June to August. Throughout these months, the northern Queen Elizabeth Islands have relatively high radiation, which decreases towards the western sector. Both seasonal and spatial variations of solar radiation may be related to the distribution of clouds.
\end{abstract}

Key words: Arctic, clouds, solar radiation

RÉSUMÉ. En raison du nombre limité de stations météorologiques dans l'archipel Arctique canadien, on n'a pas pu établir une cartographie de la radiation incidente à ondes courtes. Le modèle d'une couche de nuages, réalisé à partir d'observations nuageuses rapportées par des études estivales sur le terrain effectuées dans le cadre de l'Étude du plateau continental polaire, permet de calculer le montant de radiation solaire pour ces sites de l'Arctique dispersés sur un vaste territoire. Les valeurs calculées ont été combinées aux valeurs mesurées dans les stations météorologiques afin d'examiner les variations temporelles et spatiales de la radiation estivale. Pour les années de l'étude (1974-93), la radiation incidente à ondes courtes était la plus forte en juin et déclinait ensuite. À échelle locale, les nuages bas le long de la côte qui sont présents en abondance durant les périodes d'eau libre réduisent la réception de radiation solaire, mais la variabilité locale ne masque probablement pas les tendances régionales. À échelle régionale, la plupart des camps sur le terrain ont une forte corrélation avec les stations météorologiques les plus proches. Les données à court terme obtenues sur le terrain durant l'été ont été ajustées avec les moyennes à long terme des stations météorologiques pour établir la cartographie de la radiation solaire pour les mois de juin à août. Durant ces mois, la partie septentrionale des îles de la Reine-Élisabeth a une radiation relativement élevée, qui décroît lorsqu'on s'éloigne vers l'ouest. Les variations saisonnières comme spatiales de la radiation solaire peuvent être reliées à la distribution des nuages.

Mots clés: Arctique, nuages, radiation solaire

Traduit pour la revue Arctic par Nésida Loyer.

\section{INTRODUCTION}

The limited climatic information available in the Canadian Arctic Archipelago prevents adequate mapping of various climatic variables on a regional scale. At present, only four weather stations exist in the Queen Elizabeth Islands (Fig. 1), even though scenarios of climatic change suggest that the Arctic will be sensitive to global warming (Schlesinger and Mitchell, 1987). The feedback between radiation and the snow and ice surfaces, together with possible changes in the clouds over the arctic basin, will add complexity to the energy balance in such latitudes (Roots, 1989). Thus the mapping resolution of the climatic elements must be refined to provide useful spatial data needed by different branches of arctic sciences. Such data will also provide the base for monitoring future changes.

Edlund and Alt (1989) used weather station data, supplemented by weather information from arctic field camps, to improve the regional maps of cloud cover, temperatures, and precipitation for the summer months. These maps are more detailed than and sometimes deviate from those derived from weather station data alone (Maxwell, 1980, 1982).

Edlund and Alt (1989) did not offer maps of solar radiation. However, the spatial distribution of solar radiation has applications to climatology (Kane et al., 1992; Rouse et al., 1992), hydrology (Young and Lewkowicz, 1990) and ecology

\footnotetext{
${ }^{1}$ Department of Geography, McMaster University, 1280 Main Street West, Hamilton, Ontario L8S 4K1, Canada

${ }^{2}$ Department of Geography, York University, 4700 Keele Street, North York, Ontario M3J 1P3, Canada

(C) The Arctic Institute of North America
} 


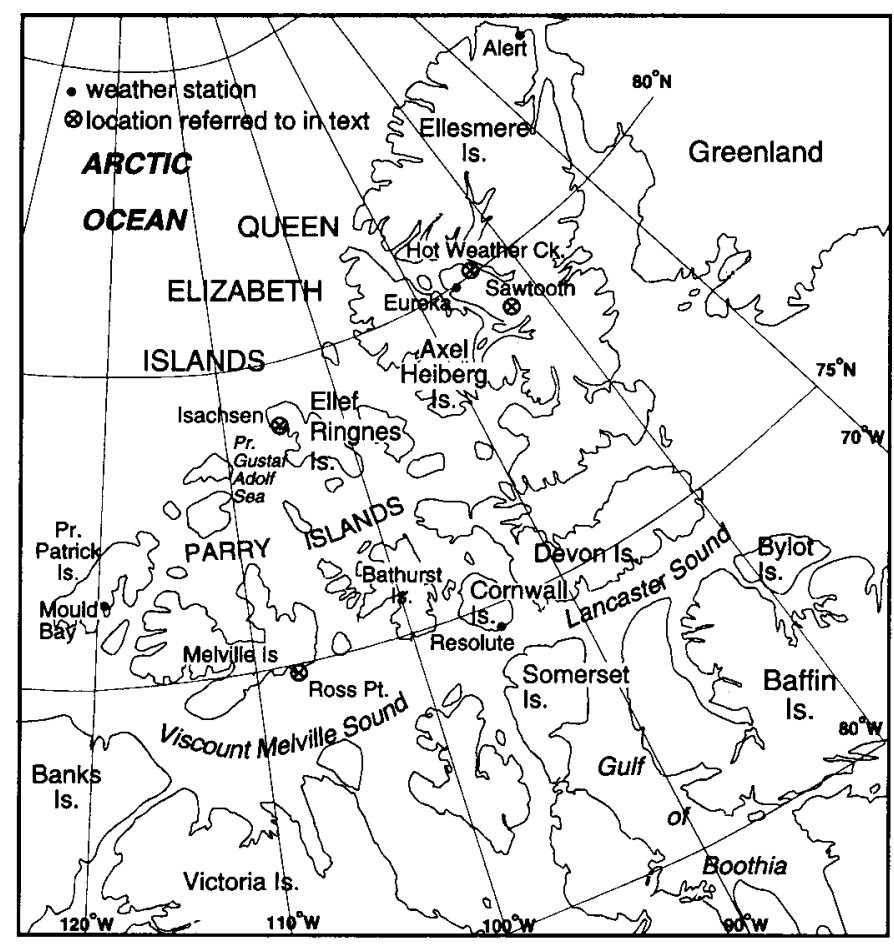

FIG. 1. Location of official weather stations that provide data for this study. Also shown are place names in the Canadian Arctic Islands mentioned in the paper.

(Oberbauer and Dawson, 1992), particularly for the summer period, when the rates of many geomorphological, hydrological and botanical processes reach high values.

An opportunity arose to model solar radiation using the weather data gathered by summer field camps and collated by the Polar Continental Shelf Project (PCSP), Natural Resources Canada. Young et al. (1995) compared several available models and indicated the feasibility of using limited cloud observations to compute radiation for arctic sites. This study will (1) demonstrate the possibility of applying a cloud layer model to calculate global radiation, (2) examine the temporal and spatial variations of global radiation in the Canadian Arctic Islands, and (3) map the regional summer radiation pattern for these latitudes using the combined weather station record and our calculated data.

\section{DATA SOURCE}

Background information regarding the physical setting of the Arctic Islands is available in Maxwell (1980) and Edlund and Alt (1989), and will not be repeated. Radiation measurements are available from five arctic weather stations: Alert (since 1964), Eureka (since 1964), Isachsen (1970-78), Mould Bay (since 1965), and Resolute (since 1957); however, only the data for 1974-93 will be used in our study, because this is the period for which the following sets of field data are available to us.

Each summer, the PCSP provides logistical support to field parties, which are required to report their weather conditions at 1200 and 0000 GMT. This standardizes the weather reporting time regardless of the longitudinal position of the field camps. Although scattered over large areas of the Arctic Islands, few camps remained in the same vicinity for more than two seasons. We were able to obtain only one year of data for 134 camps, two years of data for 35 camps, and three years of data for 15 camps; and only 5 camps offered over ten years of record. Furthermore, most camps were occupied for only a short period, ranging from two weeks to three months in each season.

Pertinent to our study are the temperature and cloud data (see Appendix). The latter are reported following the standard Environment Canada procedures, specifying cloud layer heights, amounts, and cloud types. Since only twice-daily observations are available, the cloud data taken at $1200 \mathrm{GMT}$ are considered to represent the period 0000 to $1200 \mathrm{LST}$, and the values obtained at 0000 GMT will represent the conditions from 1200 to 2400 LST.

To determine the efficacy of the cloud layer model, the calculated global radiation values were compared with measured data at two sites, using pyranometers which have a calibrated accuracy of $\pm 1 \%$ or $0.01 \mathrm{MJ} \mathrm{m}^{-2}$ per hour (Atmospheric Environment Service [AES], 1989). In 1986, measurements were made at Ross Point, Melville Island $\left(74^{\circ} 57^{\prime} \mathrm{N}\right.$, $107^{\circ} 19^{\prime} \mathrm{W}$, elevation $45 \mathrm{~m}$ ). In 1989 and 1990, the Atmospheric Environment Service provided radiation data at Hot Weather Creek, Ellesmere Island $\left(79^{\circ} 58^{\prime} \mathrm{N}, 84^{\circ} 28^{\prime} \mathrm{W}\right.$, elevation $118 \mathrm{~m})$.

\section{MODEL VALIDATION}

A cloud layer model was applied to the PCSP field camp observations to compute daily incoming shortwave radiation. The method involves (1) calculating clear-sky radiation for a particular site on a given day of the year, (2) estimating cloud amount and cloud transmissivity (based on cloud type) for low, middle and high-level cloud layers, and (3) adjusting the clear-sky radiation by the cloud effects. Details of the model can be found in Young et al. (1995). A brief description is provided in the Appendix. As an indicator of model performance, the percentage root mean square error (\%RMSE) was used (Davies et al., 1984):

$$
\% R M S E=100\left[\sum_{i=1}^{k}\left(P_{i}-O_{i}\right)^{2} / k\right]^{0.5} / \sum_{i=1}^{k} 0_{i}
$$

where $P$ and $O$ are predicted and observed values and $k$ is the number of data points.

This model has been tested previously using cloud and temperature data of Eureka. The results compare well with the solar radiation measured at the Eureka weather station, and the model was found to perform as well as or better than several other models currently available for radiation calculation (Young et al., 1995). The model was applied in the present study to two test sites, Ross Point and Hot Weather Creek. Good performance was obtained under cloudless and overcast conditions (Figs. 2 and 3). With partial cloud cover, the calculated daily radiation values corresponded less 


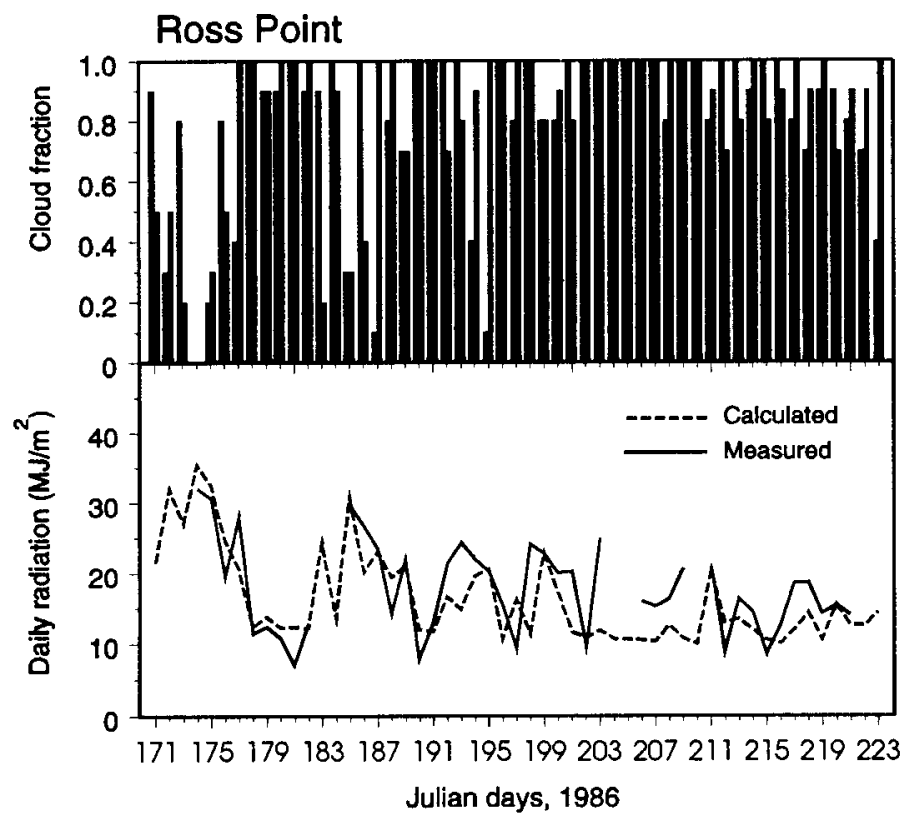

FIG. 2. Comparison of modelled and measured daily incoming shortwave radiation for Ross Point (1986). Also shown are the cloud amounts at this camp.

satisfactorily with the measured data, mainly because twicedaily cloud observations may not be applicable to those hours without cloud information, as the model assumes.

When radiation data are summed over a period of several days, the \%RMSE decreases. Figure 4 shows that when averaged over 10 days, the error fell to about $15 \%$ for Ross
Point and to $12 \%$ for Hot Weather Creek during the wet and cloudy summer of 1989; but it remained at $20 \%$ for 1990 , which had many days with partial cloud cover. A student $\mathrm{t}-$ test at the 0.95 probability level revealed that the means of predicted and observed values are not significantly different. The 1990 situation is the least favourable for the model, and the resulting \%RMSE probably approaches the maximum error for the model. In the following sections, the finest resolution for mapping will be ten-day totals of global radiation. Such a time scale remains useful for most geomorphic or ecological investigations.

\section{TEMPORAL VARIATIONS}

The spring and summer (June to August) global radiation measured at four weather stations allows the seasonal and annual rhythms to be established. The four stations are situated in the Northwestern Island Fringe (Mould Bay) and Bathurst-Prince of Wales Islands (Resolute) subregions of the Northwestern Region; and in the Nares Strait (Alert) and Nansen Sound and Adjacent Lowlands (Eureka) subregion of the Northern Region (Maxwell, 1981).

\section{Interannual Variations}

Over the period of record (up to 1957), only Resolute showed a decline in summer radiation; such a trend was not obvious in the other stations (Fig. 5). Even for Resolute, the trend was not apparent during the study years (1974-93), but

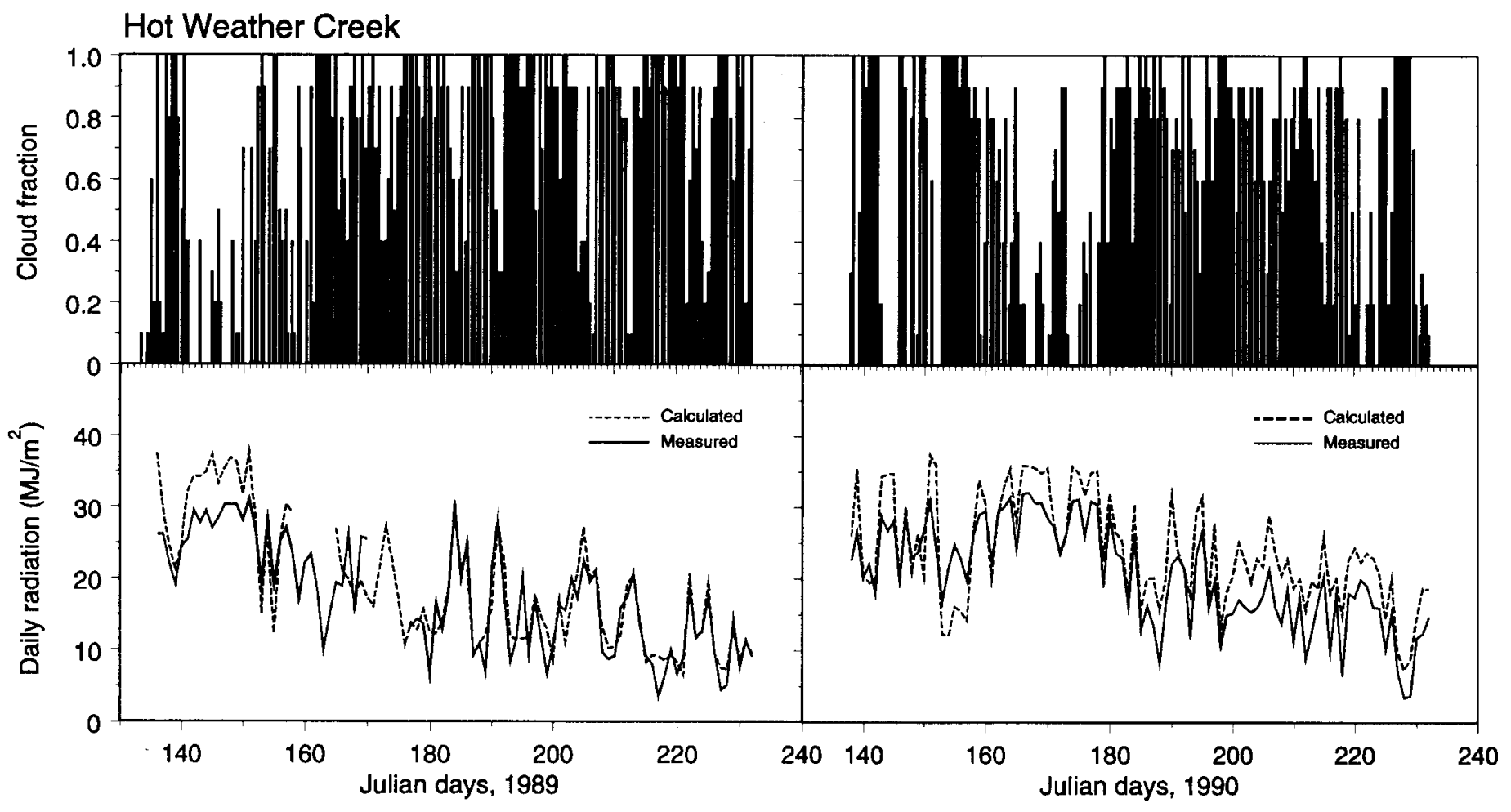

FIG. 3. Comparison of modelled and measured incoming shortwave radiation for Hot Weather Creek (1989 and 1990). Also shown are the cloud amounts. 


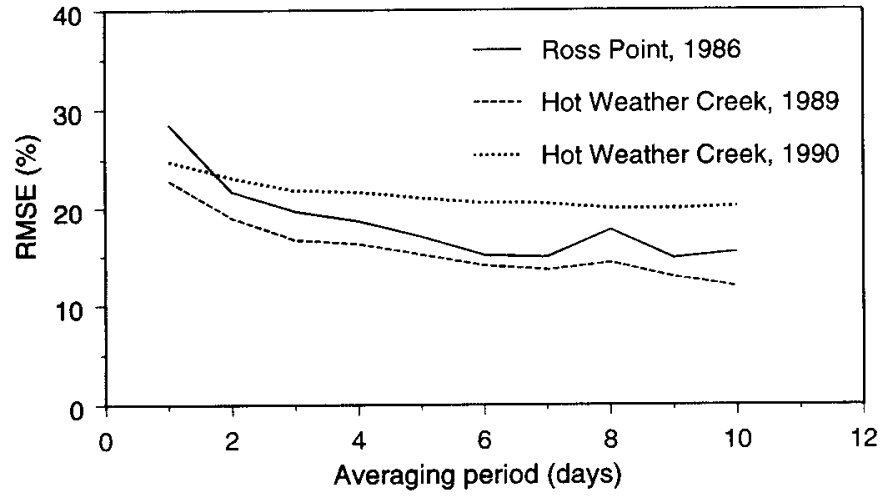

FIG. 4. Decrease of percentage root mean square error (\%RMSE) with length of averaging period for three sets of calculated incoming shortwave radiation: Ross Point (1986) and Hot Weather Creek (1989 and 1990).

Resolute did have a pattern similar to that of other Low Arctic stations such as Hall Beach $\left(68^{\circ} 47^{\prime} \mathrm{N}, 81^{\circ} 15^{\prime} \mathrm{W}\right)$ and Cambridge Bay $\left(69^{\circ} 07^{\prime} \mathrm{N}, 104^{\circ} 47^{\prime} \mathrm{W}\right)$. Eureka exhibited the largest year-to-year variations, from a low of 15.27 $\mathrm{MJ} /\left(\mathrm{m}^{2} \mathrm{~d}\right)$ in 1973 to a high of 22.75 in 1988 . Its interannual variations are closely followed by its nearest station, Alert, which lies within the same climatic region (Maxwell, 1981).

The rise and fall in summer radiation was synchronous among the four stations during some years (e.g., 1973 and 1974), but showed opposite tendencies in others: in 1980, for example, the Northern Region had an increase, but the Northwestern Region showed a decrease. These patterns clearly demonstrate the inadequacy of using a limited number of stations to interpret the interannual variability of summer radiation over the Arctic Islands. However, the regional variation of mean summer radiation is evident from the probability distribution of the June-to-August values for the four stations (Fig. 6). Mould Bay often has the lowest radiation during the summer period, while Eureka has the highest; the values for Resolute and Alert are in between.

\section{Seasonal Rhythm}

Every site in the study area receives 24 hours of daylight until mid-August. The northern parts of the Archipelago, represented by Alert and Eureka, have particularly large average shortwave radiation receipts in June, when the zenith angle is the highest during the solstice (Table 1). July and August witness prominent declines in radiation. Such tendencies are evident in the ten-day total solar radiation for the four weather stations (Fig. 7). Radiation is slightly higher around Eureka, probably because its surrounding mountains deflect or dissipate low-level clouds (Edlund and Alt, 1989).

Most field camps were not occupied long enough for their seasonal radiation regimes to be established. However, for several camps that yielded longer weather records, the calculated daily radiation values showed periods of

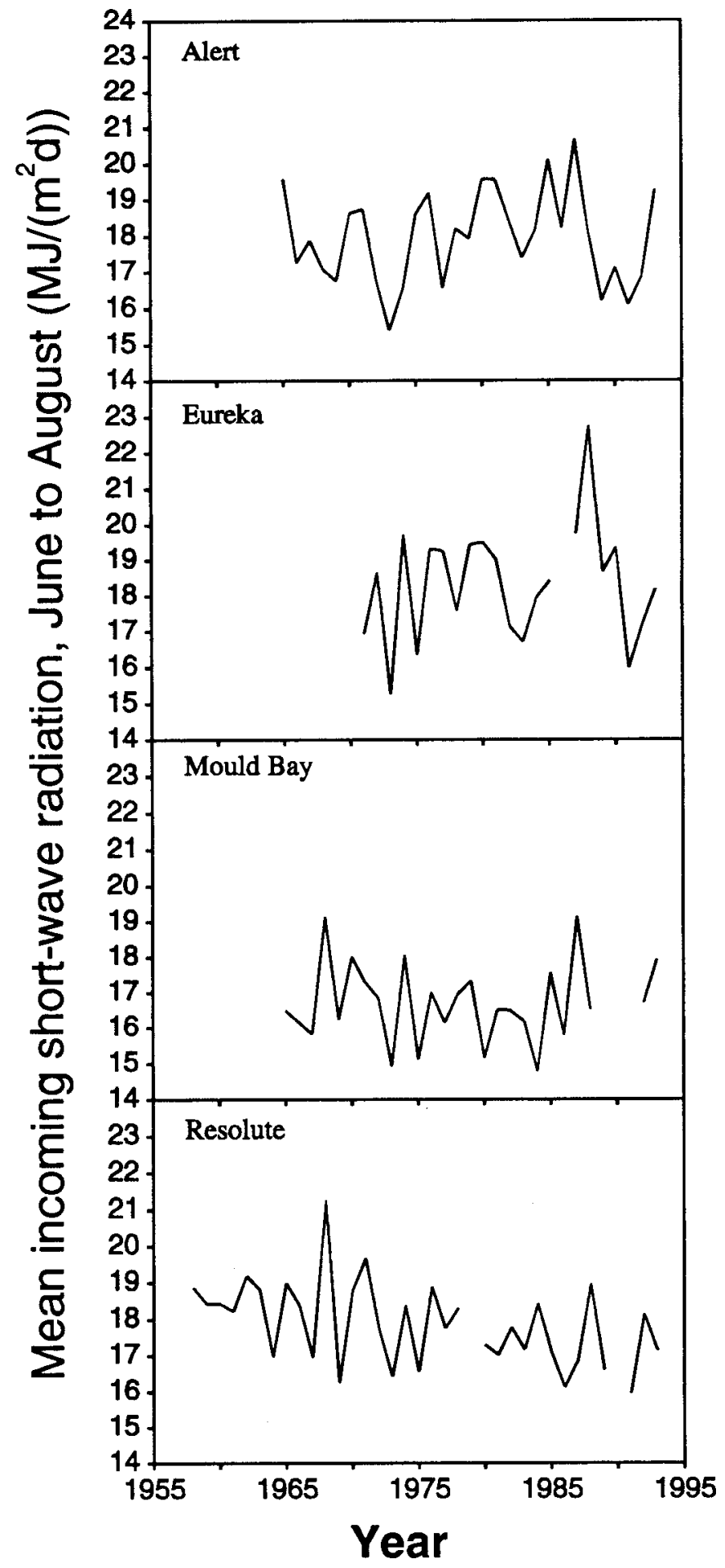

FIG. 5. Mean daily summer incoming shortwave radiation (June to August) for various years of record from four Arctic weather stations.

high or low that corresponded with those of their closest weather stations. Figure 8 indicates that Cunningham Inlet and Truelove Inlet followed the fluctuations of Resolute station and, similarly, Alexandra Fiord and Expedition Fiord showed agreement with the Eureka station. These examples suggest that the field campsites also exhibit seasonal patterns similar to those of their nearby stations. 


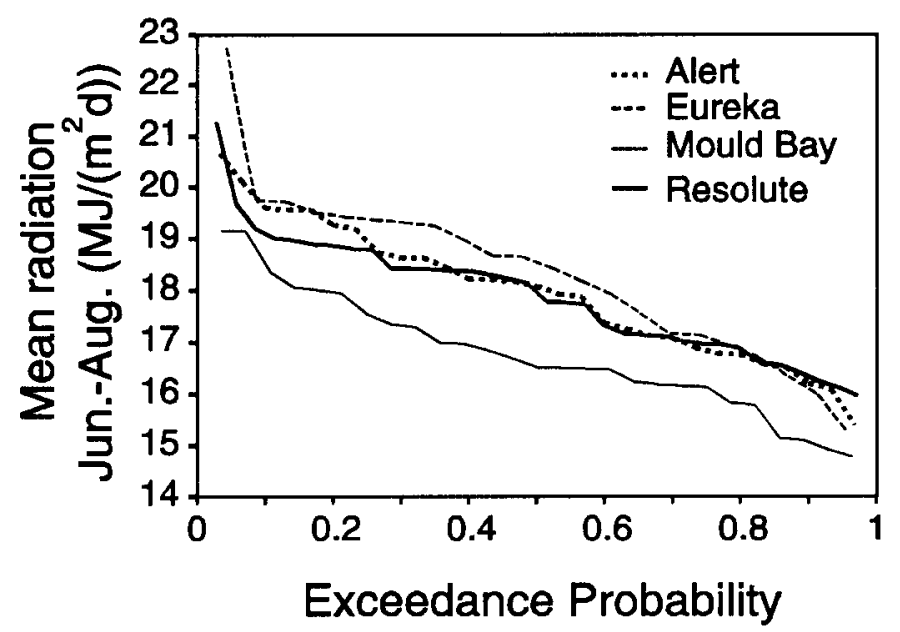

FIG. 6. Probability distributions of mean summer radiation for four Arctic weather stations.

TABLE 1. Mean daily solar radiation $\left(\mathrm{MJ} /\left(\mathrm{m}^{2} \mathrm{~d}\right)\right)$ during the summer months of June, July and August at four Arctic weather stations, averaged over the period 1974-93.

\begin{tabular}{|c|c|c|c|c|c|c|c|}
\hline & Latitude & Longitude & $\begin{array}{l}\text { Elevation } \\
\quad(\mathrm{m})\end{array}$ & June & July & Augus & $\begin{array}{l}\text { June - } \\
\text { August }\end{array}$ \\
\hline Alert & $82^{\circ} 30^{\prime} \mathrm{N}$ & $62^{\circ} 20^{\prime} \mathrm{W}$ & 63 & 25 & 18 & 11 & 18 \\
\hline Eureka & $80^{\circ} 00^{\prime} \mathrm{N}$ & $85^{\circ} 56^{\prime} \mathrm{W}$ & 10 & 25 & 20 & 11 & 18 \\
\hline Mould Bay & $76^{\circ} 14^{\prime} \mathrm{N}$ & $119^{\circ} 20^{\prime} \mathrm{W}$ & 15 & 23 & 17 & 9 & 17 \\
\hline Resolute & $74^{\circ} 43^{\prime} \mathrm{N}$ & $94^{\circ} 59^{\prime} \mathrm{W}$ & 64 & 23 & 18 & 11 & 17 \\
\hline
\end{tabular}

\section{SPATIAL VARIATION}

Combining the weather station with the field camp data, we examined the spatial distribution of global radiation during the summer. Problems can arise in mapping the radiation distribution because (1) the field camp observations may not be entirely dependable; (2) the model inputs are limited to only twice-daily cloud observations; (3) the number of camps is inadequate at any one time to cover the large region; and (4) site-specific radiation characteristics (e.g., coastal fogs) may affect the broad spatial patterns for the area. Both local and regional sources of variation are examined below.

\section{Local Variations}

At many coastal sites during the summer, local reduction in solar radiation may be attributed to the occurrence of fog and low clouds when the straits, sounds, and inlets experience open-water conditions (Barry and Hare, 1974). Sometimes, the low-lying areas may receive considerably less radiation than the zones above the cloud tops (Jacobs and Andrews, 1983).

The higher ground away from the coastal strips may not always have stronger radiation than the lowland. A comparison of the 1993 values for Hot Weather Creek $(118 \mathrm{~m})$ and Sawtooth Glacier (1200 m) on the Fosheim Peninsula, Ellesmere Island, shows no persistent difference between these

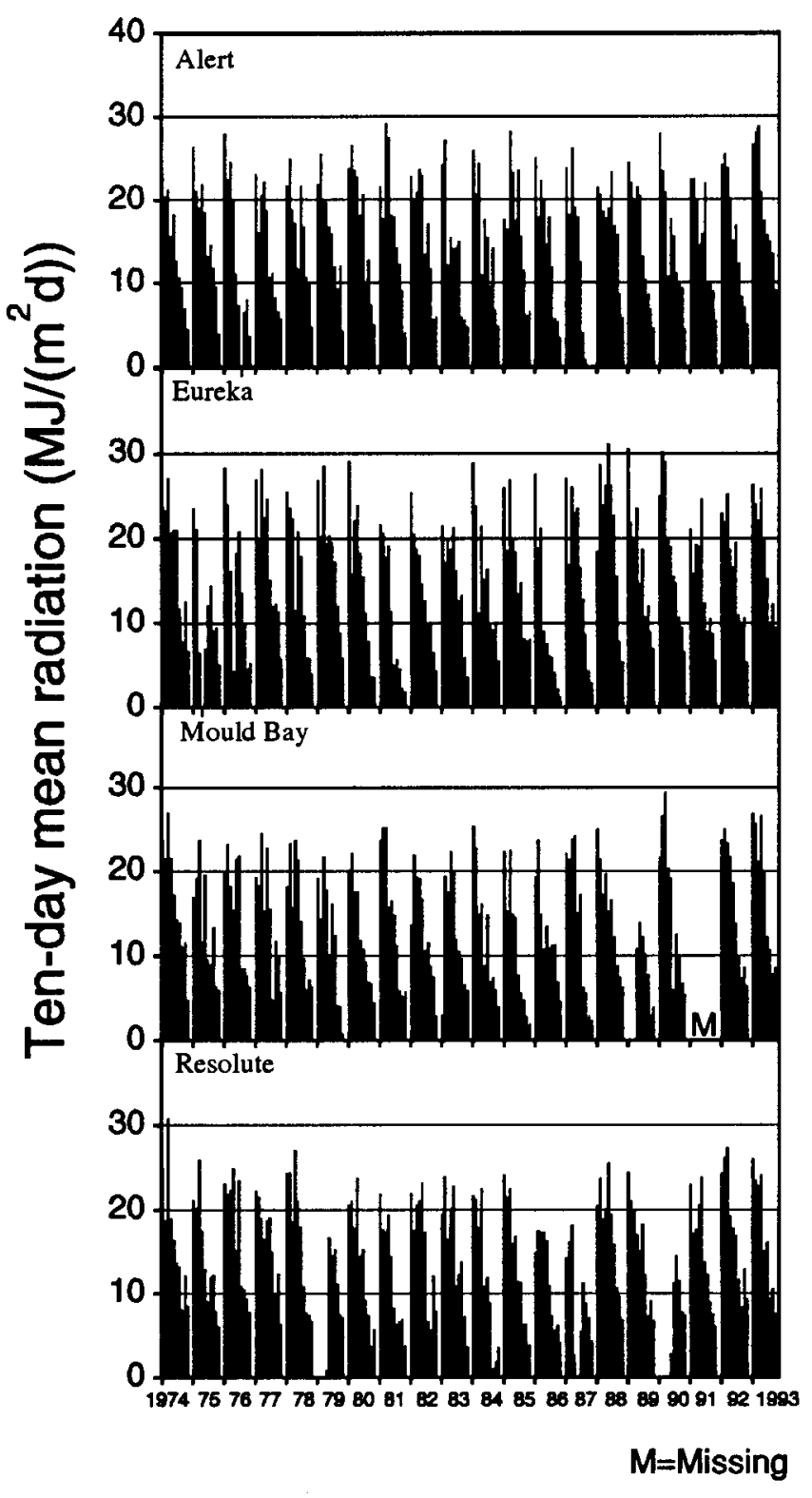

FIG. 7. Ten-day mean incoming shortwave radiation for the months of June to August, measured at four Arctic weather stations from 1974 to 1993.

sites, which are only about $40 \mathrm{~km}$ apart. In June, when there were sunnier periods, the Sawtooth Glacier site had more intense radiation (total of $774 \mathrm{MJ} / \mathrm{m}^{2}$ ) than Hot Weather Creek $\left(734 \mathrm{MJ} / \mathrm{m}^{2}\right)$. During periods of increased cyclonic activities, such as July, clouds were more prevalent in the mountains to reduce the radiation (total $632 \mathrm{MJ} / \mathrm{m}^{2}$ ) and the lowland site had more radiation input $\left(651 \mathrm{MJ} / \mathrm{m}^{2}\right)$. Over a one-month period, such local differences are small and are unlikely to confound the spatial information on a regional scale.

\section{Regional Variations}

Sufficient sites were available in 1975 and 1976 to study the changing patterns of solar radiation. Figures 9 and 10 show the average radiation values for comparable ten-day periods between June and August in 1975 and 1976. 

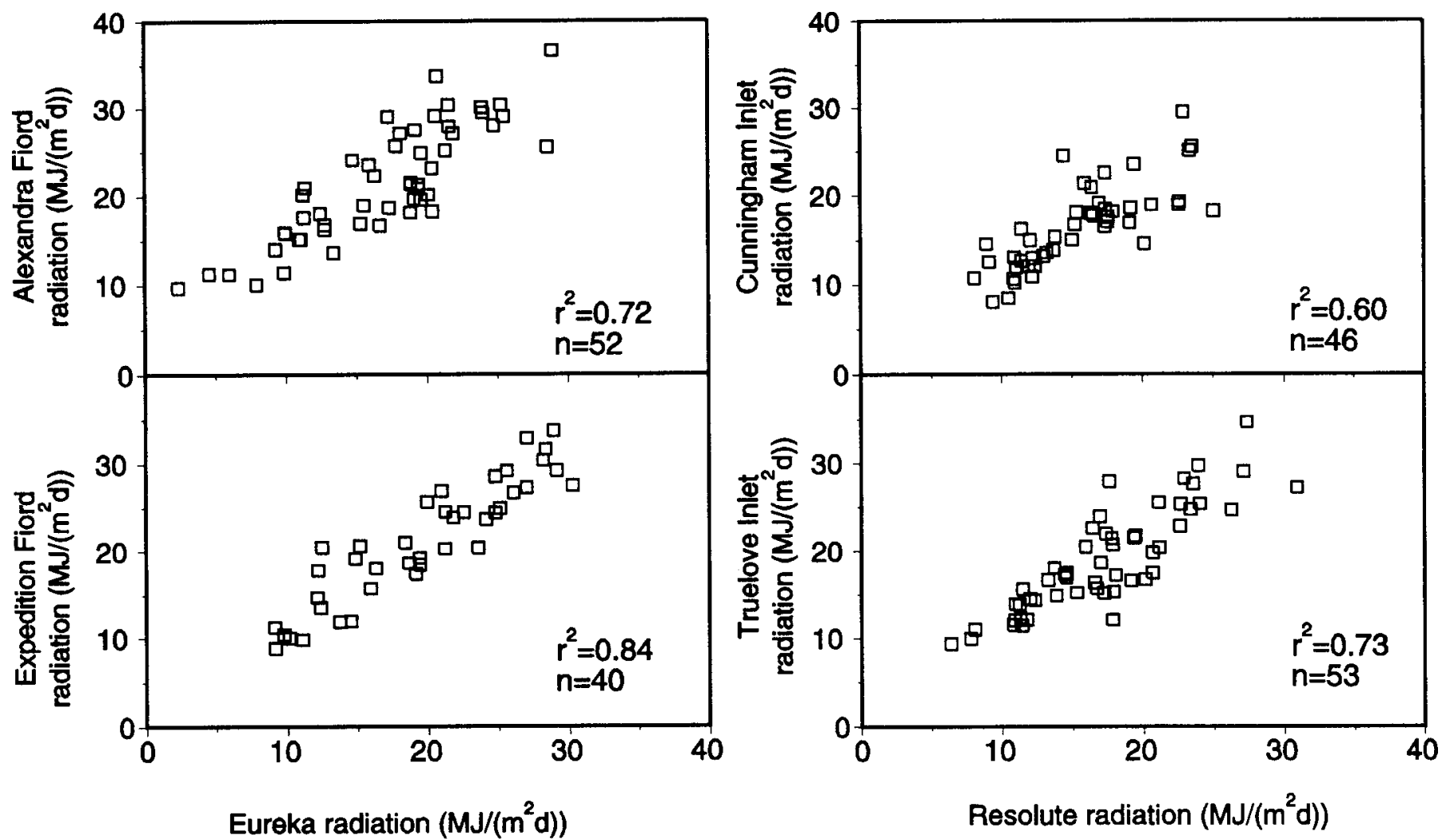

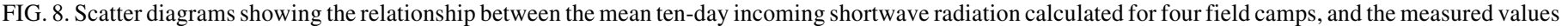
for Resolute and Eureka.
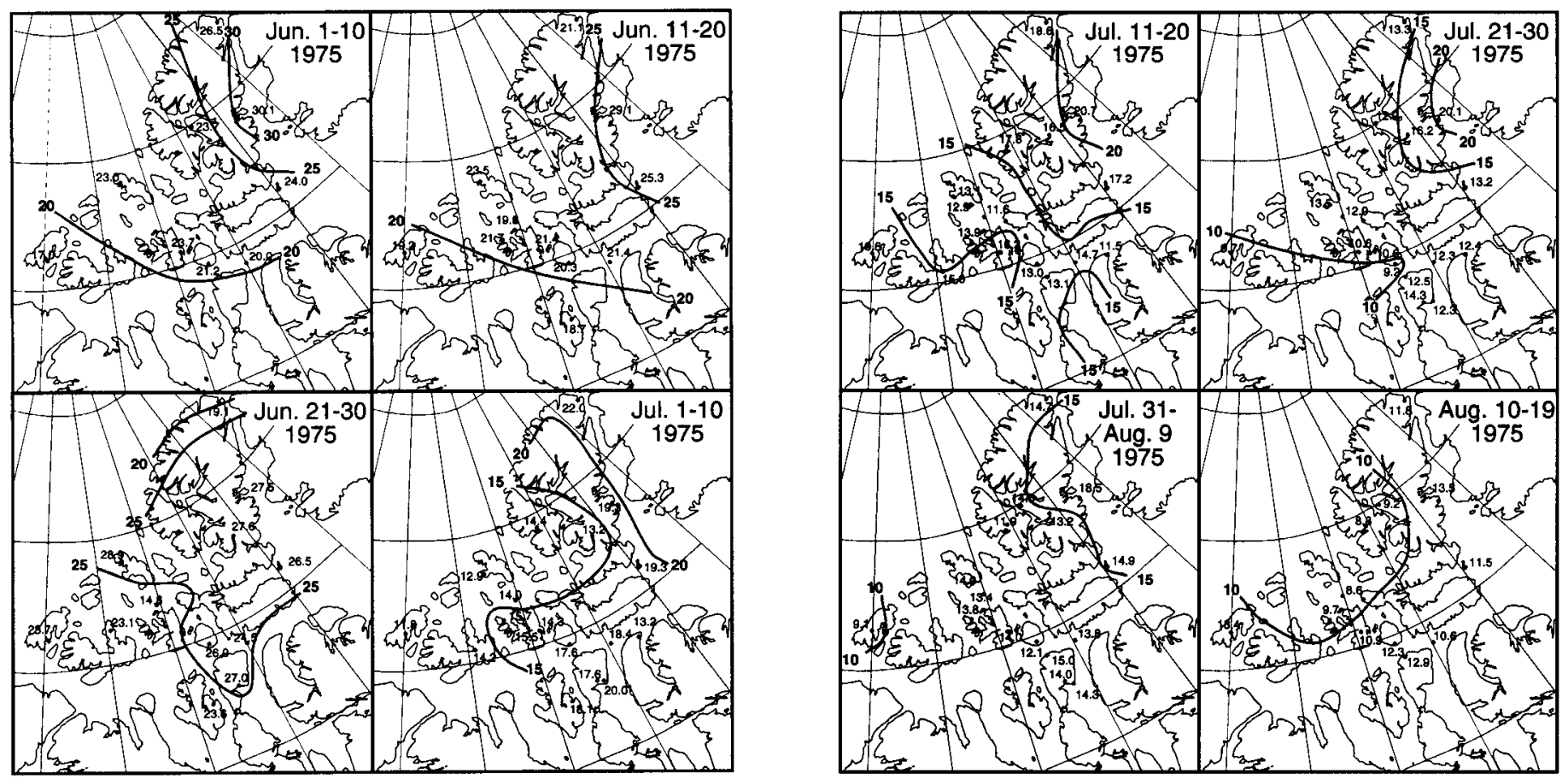

FIG. 9. Distribution of solar radiation for various ten-day periods, June-August, 1975. All values are given in $\mathrm{MJ} /\left(\mathrm{m}^{2} \mathrm{~d}\right)$.

High radiation prevailed in early June 1975 , reaching 30 $\mathrm{MJ} /\left(\mathrm{m}^{2} \mathrm{~d}\right)$ when averaged over ten-day periods in eastern Ellesmere Island, and decreasing westward towards Prince
Patrick Island. Mountain ranges in the east often restrict western cyclonic systems from entering (Maxwell, 1980). The east-west gradient continued, but it weakened in July 


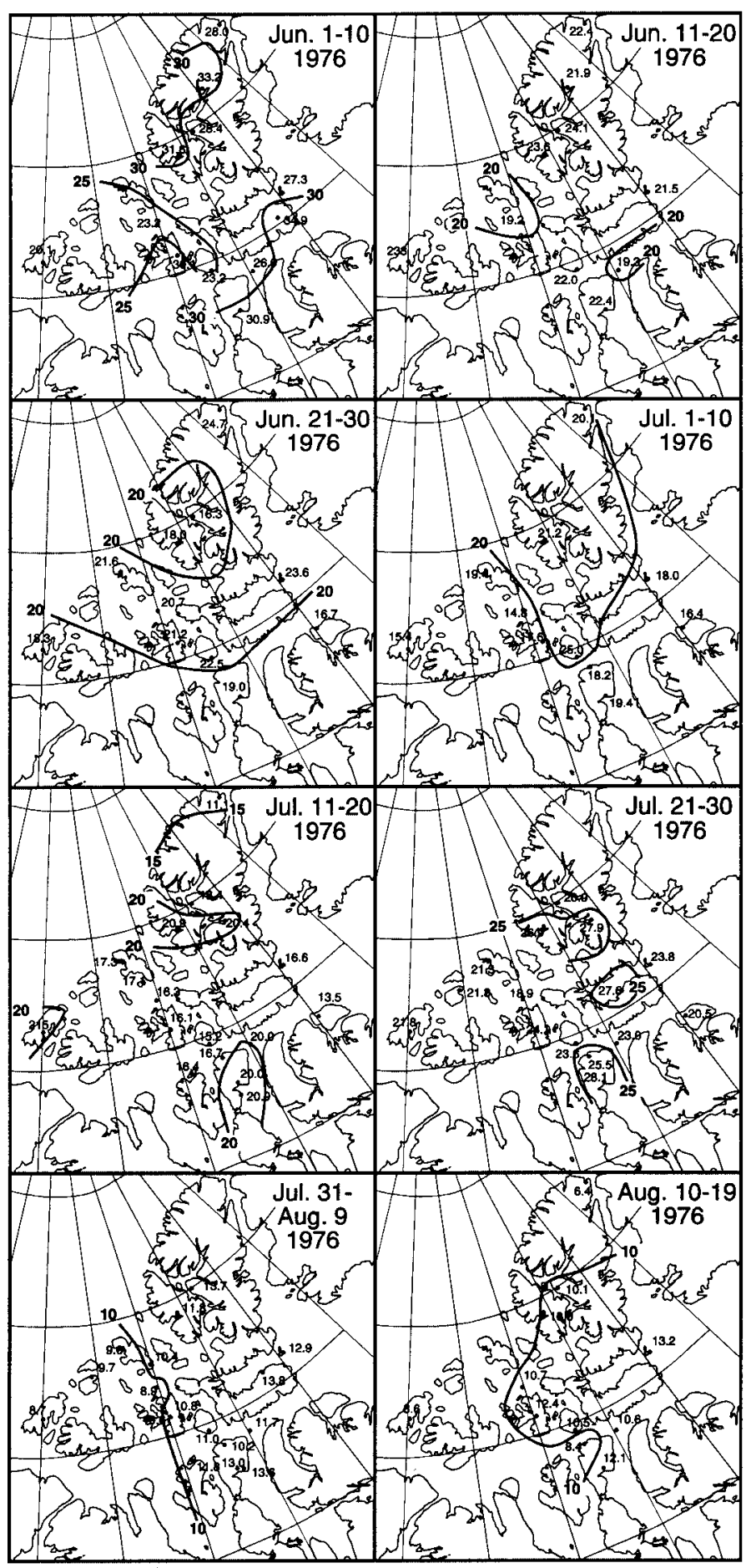

FIG. 10. Distribution of solar radiation for various ten-day periods, JuneAugust, 1976. All values are given in $\mathrm{MJ} /\left(\mathrm{m}^{2} \mathrm{~d}\right)$.

after the summer solstice, when radiation declined over the entire area. In August, the same trend was maintained, with Ellesmere Island receiving over $10 \mathrm{MJ} /\left(\mathrm{m}^{2} \mathrm{~d}\right)$ and the Parry Islands getting the lowest amount of solar radiation. Two factors explain lower radiation receipt in July and August: increased cyclonic activity, particularly near the mainland; and maximum precipitable water in the arctic atmosphere, which makes July, August, and September generally the wettest months (Maxwell, 1982).

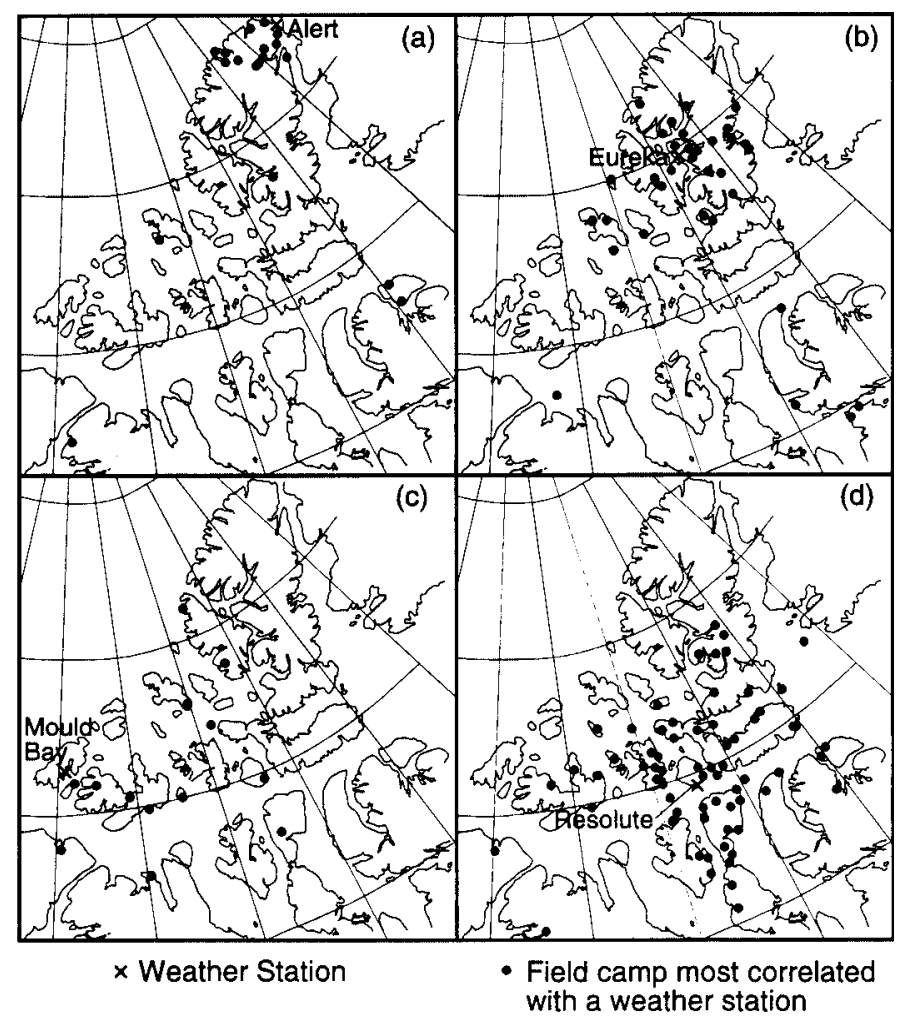

FIG. 11. Distribution of field camps with incoming shortwave radiation that correlates most highly with (a) Alert, (b) Eureka, (c) Mould Bay and (d) Resolute.

In early June of 1976, western Ellesmere and Axel Heiberg Islands, together with eastern Devon and southern Somerset Islands, were zones of high radiation, while the western sector again received lower radiation. This pattern weakened in mid-June and then changed, to yield an arc of high radiation input that extended from eastern Ellesmere and Devon Islands to Cornwallis and Bathurst Islands, and then to Ellef Ringnes Island. July of 1976 delivered more shortwave radiation to the Arctic Islands than July of 1975 . There were no strong regional patterns of radiation distribution; however, in August, the eastern parts of the Arctic Islands tended to have slightly higher radiation than the west. It is not feasible to map the radiation distribution for other years, because of data shortage. However, the patterns exhibited in 1975 and 1976 suggest no consistency from year to year, or from one period to another within a year. One generalization we can make is that during most of the time, there was a broad east-to-west gradient across the Arctic Islands.

\section{CORRELATION OF STATION AND CAMP DATA}

Despite the relatively large error associated with daily radiation calculations, the computed daily values for most field camps were found to correlate significantly (at 0.95 probability level) with one or more of the weather stations. The numerical values of the correlation coefficients between individual camps and the stations tended to be highly variable. However, some spatial patterns emerged when we plotted each weather station with its most highly correlated 


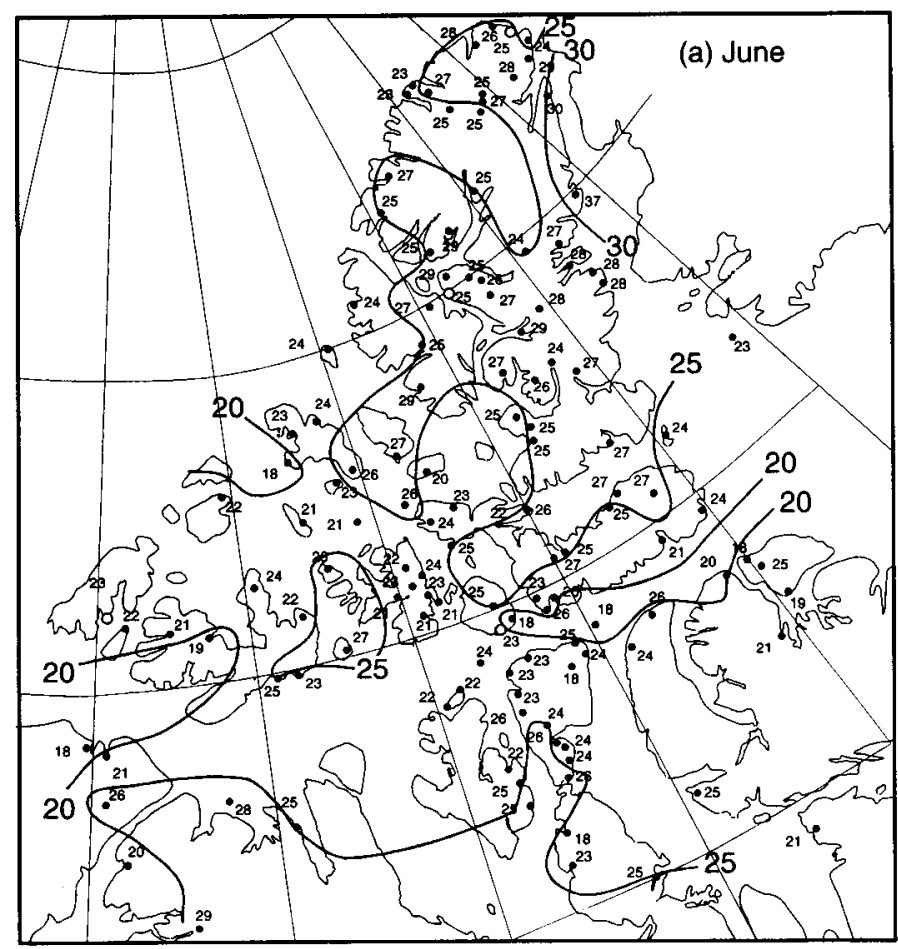

camps. Figure 11 shows the clustering of field camps that are most related to each of the four stations. Several features are evident. (1) Most camps tend to be highly correlated with the closest weather station; (2) thus, each station is surrounded by a group of camps, e.g., camps north of $83^{\circ} \mathrm{N}$ are most correlated with Alert, or most camps between $77^{\circ}$ and $83^{\circ} \mathrm{N}$ are best correlated with Eureka. (3) Resolute has the most extensive list of highly correlated field camps, suggesting that its radiation regime may be shared by most of the field sites. (4) Some camps south of Lancaster Sound and Viscount Melville Sound and around the Gulf of Boothia are more correlated with Alert or Eureka, despite their considerable distance from these stations. This suggests that the radiation regimes of these southerly sites are more akin to the extreme north than to the southern Queen Elizabeth Islands.

\section{MAPPING SUMMER RADIATION}

All field camps that correlated significantly with a weather station were used to provide estimated values of summer (June to August) radiation. The camp data were adjusted to the long-term mean by:

$$
\mathrm{G}_{\mathrm{c}}=\left(\mathrm{R}_{\mathrm{c}} / \mathrm{R}_{\mathrm{w}}\right) \mathrm{G}_{\mathrm{w}}
$$

where $G_{c}$ is the mean radiation for the camp, adjusted using the mean radiation of the weather station $G_{w}$, and $R_{c}$ and $R_{w}$ are the radiation values for the camp and the station during the period when data were available from the camp. Figure 12 combines the mean global radiation of June to August for the camps and the four weather stations. Values are given in $\mathrm{MJ} /\left(\mathrm{m}^{2} \mathrm{~d}\right)$.

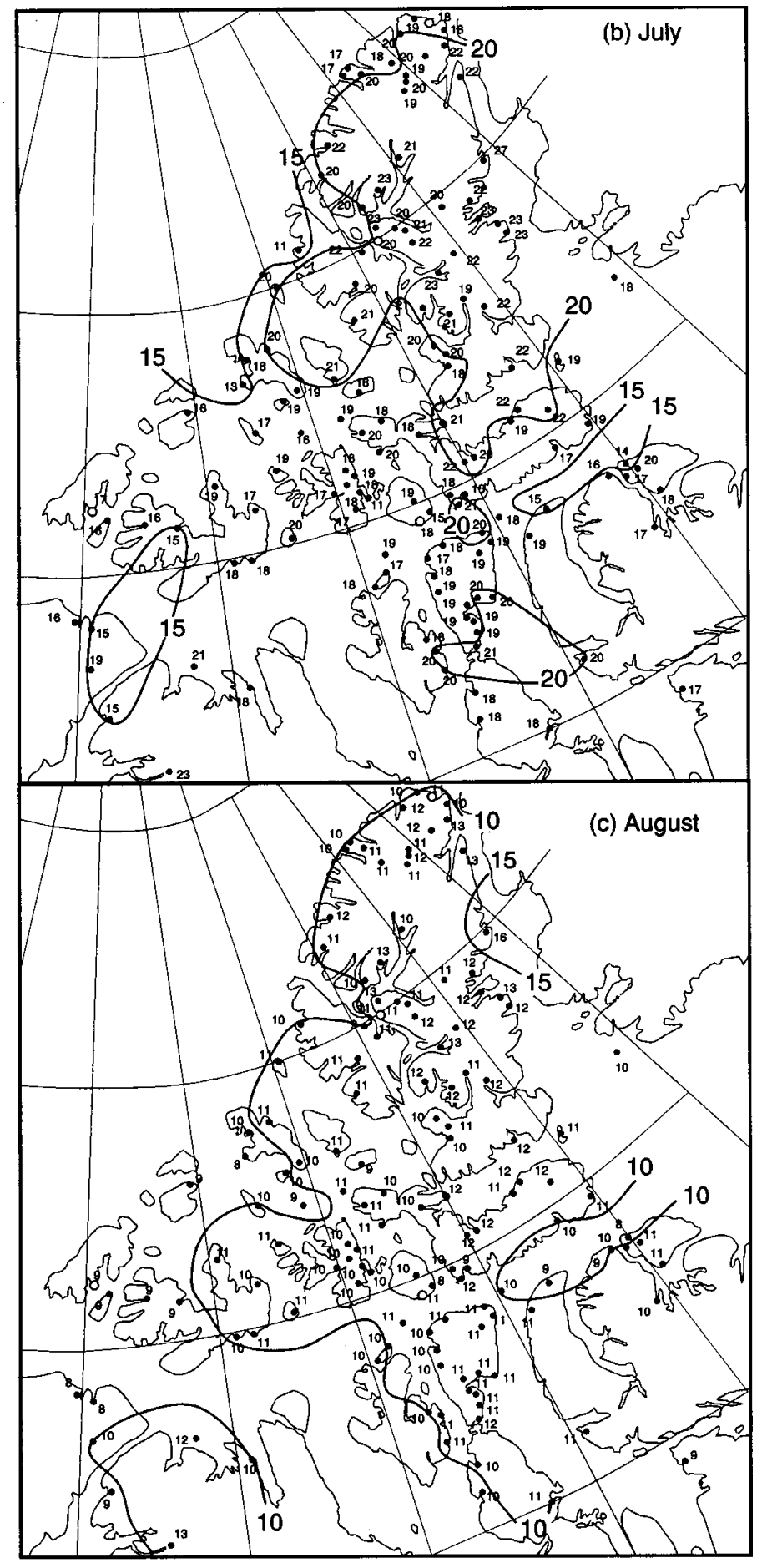

FIG. 12. Distribution of solar radiation, Canadian Arctic Islands, for (a) June, (b) July, and (c) August. All values are given in $\mathrm{MJ} /\left(\mathrm{m}^{2} \mathrm{~d}\right)$. The weather station (open circle) data are measured, while the field camp (black dot) data are calculated.

Two locational characteristics of many field camps are their proximity to the coast and the rarity of sites at high elevations. Isolines on the maps were interpolated subjectively, generalized over many areas without radiation data. The maps are based essentially upon global radiation patterns for coastal zones, extrapolated over the interior of the islands. On the other hand, there were very few 
anomalies (suggested by a single site's yielding a value that departs noticeably from those of the neighbouring locations). This lends confidence to the overall patterns depicted by the maps.

Although Figures 12a-c indicate the average summer solar radiation pattern over the arctic region, Figures 9 and 10 indicate that this pattern can depart significantly from the average from year to year. For example, in 1975 during the period (July 31-Aug. 9) almost 50\% of the Arctic Islands were receiving less than $10 \mathrm{MJ} /\left(\mathrm{m}^{2} \mathrm{~d}\right.$ ) (see Fig. 9); whereas in 1976, during the same period, only sites along the western edge of Prince Patrick Island had values less than $10 \mathrm{MJ} /$ $\left(\mathrm{m}^{2} \mathrm{~d}\right)$ (see Fig. 10).

The map for June (Fig. 12a) features high radiation $(>25$ $\mathrm{MJ} / \mathrm{m}^{2} \mathrm{~d}$ ) for Ellesmere and Axel Heiberg Islands, particularly along their flanks. A few sites in the south also suggest high radiation for the interiors of Banks and Victoria Islands. Several zones with radiation below $20 \mathrm{MJ} /\left(\mathrm{m}^{2} \mathrm{~d}\right)$ occur along the 75th parallel and around the Prince Gustaf Adolf Sea. In July (Fig. $12 \mathrm{~b}$ ), belts of high radiation $\left(>20 \mathrm{MJ} / \mathrm{m}^{2} \mathrm{~d}\right.$ ) remain on the eastern and western edges of Ellesmere Island. The Lancaster Sound area and some areas west of $100^{\circ} \mathrm{W}$ receive less than $15 \mathrm{MJ} /\left(\mathrm{m}^{2} \mathrm{~d}\right)$. As radiation decreases in August (Fig. 12c), a weak east-to-west gradient evolves. Ellesmere, Axel Heiberg, northern Devon, Bylot and Somerset Islands receive $>10 \mathrm{MJ} /\left(\mathrm{m}^{2} \mathrm{~d}\right)$. Radiation is reduced along the edge of the Arctic Ocean, falling further towards the periphery of the Beaufort Sea.

These maps are compared with the only set of radiation maps based on observed data (Maxwell, 1980), averaged for the period 1970-76 (Fig. 13a,b). Our maps include sites with higher values, but the overall radiation distribution patterns of both map sets are in agreement. In June, the northeastern parts of the Arctic Archipelago receive higher radiation than elsewhere, and in July, an east-to-west gradient develops. With more data points available, our maps reinforce Maxwell's conclusions with greater detail.

\section{DISCUSSION AND CONCLUSIONS}

Clouds play an important role in attenuating solar radiation. This study demonstrates the usefulness of applying a cloud layer model to determine incoming shortwave radiation. The model is particularly applicable to the Arctic, where low clouds are abundant and persistent. Such clouds can be identified easily even by inexperienced observers, and the cloud amount can be estimated without much error. Taking advantage of the robustness of the model, we calculated daily radiation for remote sites, using cloud observations made at field camps, to permit improved mapping of summer radiation distribution in the Arctic Islands.

Daily radiation calculated for most field camps was found to be correlated significantly with measurements from one of the arctic weather stations. All stations and field camps show prominent seasonal fluctuations in response to three factors: (1) the natural rhythm of solar radiation which peaks around

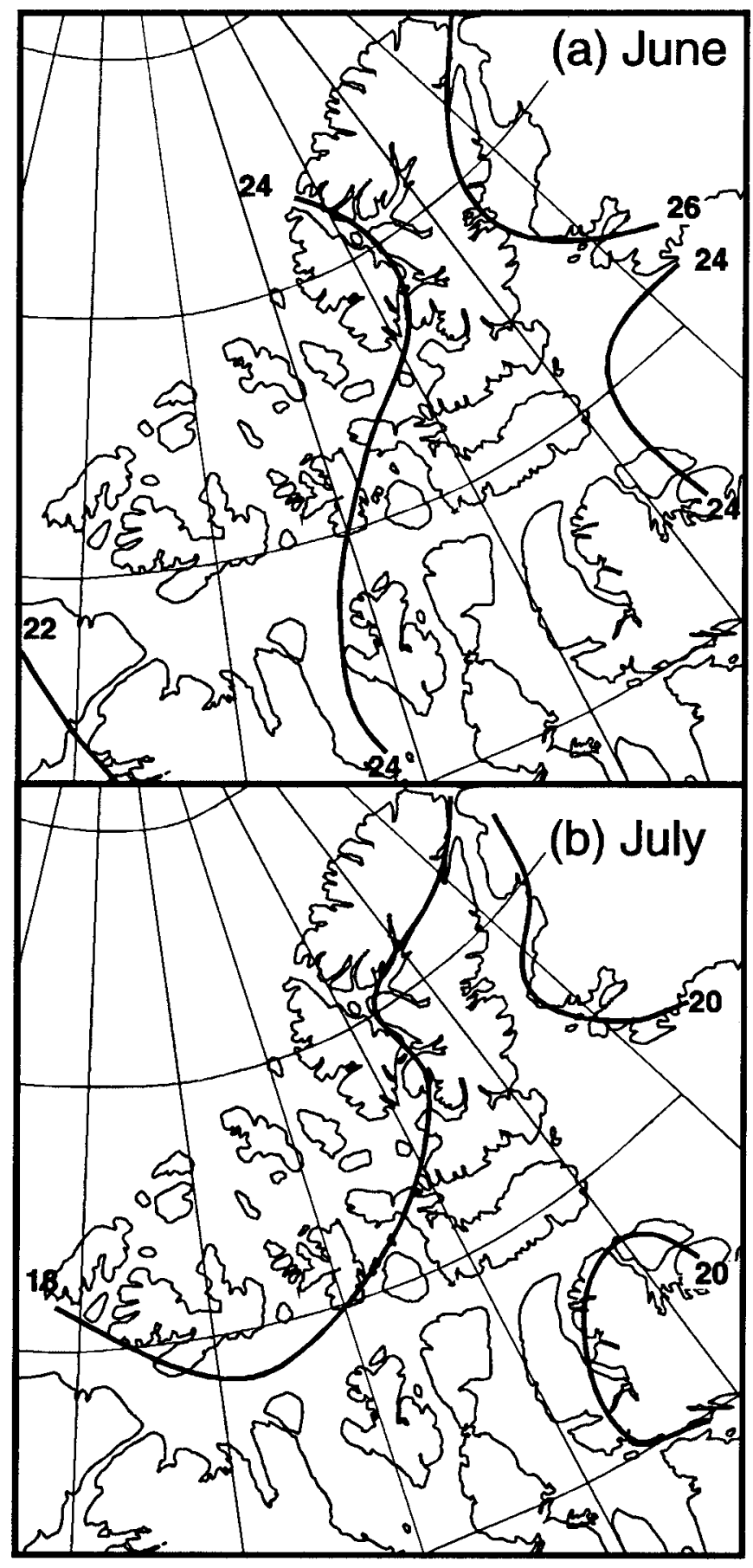

FIG. 13. Distribution of solar radiation (in $\mathrm{MJ} /\left(\mathrm{m}^{2} \mathrm{~d}\right)$ ) for (a) June and (b) July, based on observations of 1970 - 76 (modified after Maxwell, 1982).

the summer solstice; (2) high pressure in June associated with fewer clouds to obscure radiation receipt, followed by frequent passage of frontal depressions and cloudiness in July and August; and (3) the formation of coastal fog and stratus clouds during late summer when open water conditions occur (Sim, 1957). These situations combine to yield high radiation in June and reduced radiation in late summer. Overall, since considerable variation can occur from year to year (see Figs. 9 and 10), caution should be exercised when using average patterns of solar radiation for the Arctic region as a whole. 


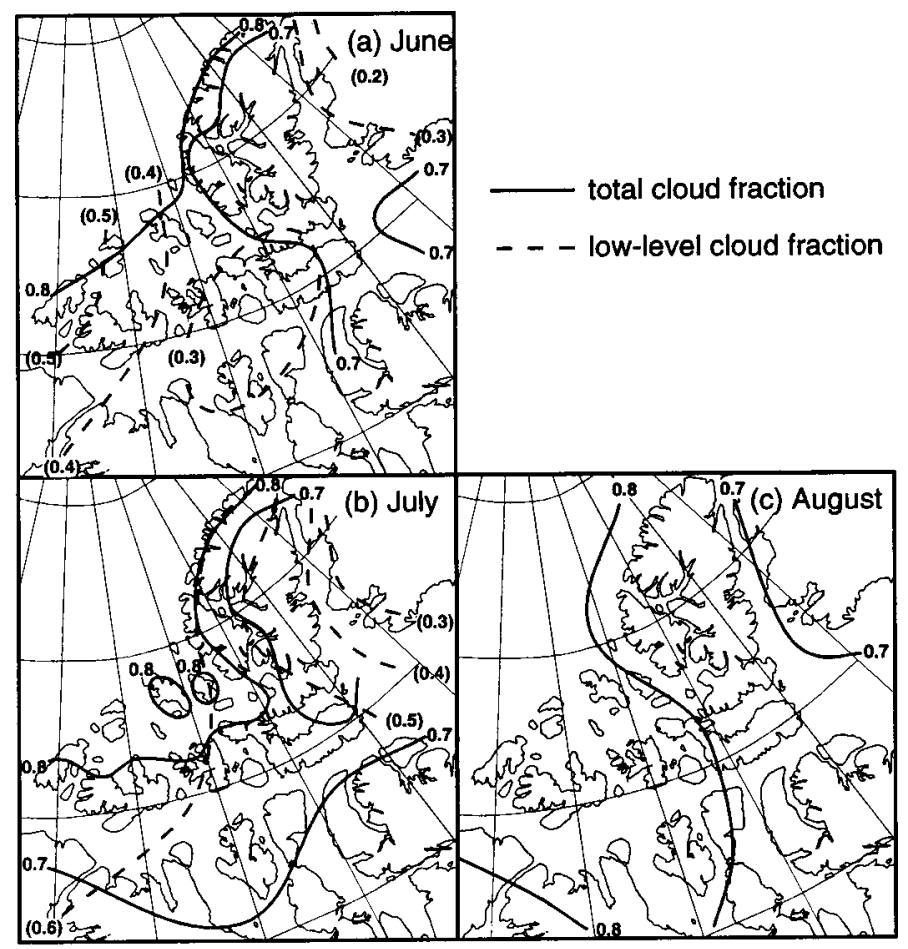

FIG. 14. Total cloud amount (full lines) and low-level cloud amount (dashed lines) for (a) June, (b) July and (c) August. Total cloud cover after Edlund and Alt (1989) and Maxwell (1982); low-level cloud cover after Vowinckel (1962).

The spatial variation of solar radiation may be related to the distribution of clouds, particularly the amount of lowlevel cloud (Vowinckel, 1962; Maxwell, 1982; Edlund and Alt, 1989). Figure 14a shows that the cloud fraction for the eastern Arctic Islands averages $<0.7$, and the northeastern zone has a notably small fraction of low clouds (about 0.3 ). These correspond with the zones of high radiation in June (Fig. 12a). Total cloud amounts increase in July, particularly in the Parry Islands, as do low-level clouds (Fig. 14b). Cloudiness decreases south of Viscount Melville Sound and Lancaster Sound. The general disposition of solar radiation (Fig. 12b) reflects these cloud patterns, with higher values in the east and low values in the western sector. In August, larger cloud amounts intrude south of Viscount Melville Sound (Fig. $14 \mathrm{c}$ ), and the $<10 \mathrm{MJ} /\left(\mathrm{m}^{2} \mathrm{~d}\right.$ ) radiation zone (Fig. 12c) compares very well with the $>0.8$ cloud-covered area.

These facts suggest a feasible method of expanding the climatic database for the Arctic, where such information is scarce. The augmentation of radiation data using cloud and temperature data demonstrates the usefulness of gathering and archiving field camp observations. Thus, the practice of obtaining weather observations at Arctic field camps should be encouraged to continue.

\section{ACKNOWLEDGEMENTS}

This work is supported by a contract from the Atmospheric Environment Service. The Polar Continental Shelf Project made available the weather observations made at the summer field camps it supported. We thank Dr. Bea Alt, Dr. Barry Maxwell, and Mr. Angus Headley for facilitating the retrieval of data.

\section{APPENDIX}

Global radiation is calculated for an arctic site using a cloud layer model, as follows:

(1) The theoretical estimate of cloudless sky irradiance $\left(\mathrm{G}_{0}\right)$ is computed following the method in Paltridge and Pratt (1976), by considering the solar constant, the solar zenith angle (which is a function of latitude, day of the year, and hour of the day), the sun-earth distance, absorptance by water vapour, and transmittances that account for ozone absorption, Rayleigh scattering, aerosol absorption, and aerosol scattering. The absorptance by water vapour is related to the precipitable water, which is computed from mean air temperature and elevation (Deacon, 1970). For the present study, both aerosol absorption and scattering are considered to be 1.0.

(2) The presence of clouds reduces the theoretical irradiance. For the cloud layer model, global radiation $(G)$ is calculated using information from $\mathrm{j}$ cloud layers:

$$
G=G_{0} \underset{i=1}{j}\left(1-C_{i}+C_{i} T_{i}\right) /(1-0.16 b)
$$

where $\mathrm{C}_{\mathrm{i}}$ and $\mathrm{T}_{\mathrm{i}}$ are the cloud amount and the transmittance of cloud layer $\mathrm{j}$, and $\mathrm{b}$ is the back-scattering coefficient, evaluated by (Davies and McKay, 1982):

$$
b=0.0685(1-n)+0.6 n
$$

with $\mathrm{n}=\Sigma \mathrm{C}_{\mathrm{i}}$ being the total cloud fraction.

(3) Three cloud heights are considered in this study. Their average transmittances are 0.32 for low clouds (stratus), 0.42 for middle-layer clouds (alto-stratus), and 0.78 for high clouds (cirrus). Thus, the abundance of low clouds can significantly attenuate radiation.

\section{REFERENCES}

ATMOSPHERIC ENVIRONMENT SERVICE. 1989 AES guidelines for co-operative climatic autostations. Downsview, Ontario: Canadian Climate Centre. 59 p.

BARRY, R.G., and HARE, F.K. 1974. Arctic climate. In: Ives, J.D., and Barry, R.G., eds. Arctic and alpine environments. London: Methuen. 17-54.

DAVIES, J.A., and McKAY, D.C. 1982. Estimating solar irradiance and components. Solar Energy 29:55-64.

DAVIES, J.A., ABDEL-WHAHAB, M., and McKAY, D.C. 1984. Estimating solar irradiation on horizontal surface. International Journal of Solar Energy 2:405-424. 
DEACON, E.L. 1970. The derivation of Swinbank's longwave radiation formula. Quarterly Journal of the Royal Meteorological Society 96:313-319.

EDLUND, S.A., and ALT, B.T. 1989. Regional congruence of vegetation and summer climate patterns in the Queen Elizabeth Islands, Northwest Territories, Canada. Arctic 42:3-23.

JACOBS, J.D., and ANDREWS, J.T. 1983. A note on solar radiation measurements on Cumberland Peninsula, Baffin Island, N.W.T., Canada in summer, 1970 to 1979. Arctic and Alpine Research 15:91-96.

KANE, D.L., GIECK, R.E., WENDLER, G., and HINZMAN, L.D. 1992. Snowmelt at a small Alaskan Arctic watershed. 2. Energy related modelling results. 9th International Northern Research Basins Symposium/Workshop, Canada, National Hydrological Research Institute, Symposium No. 10. 227-247.

MAXWELL, J.B. 1980. The climate of the Canadian Arctic Islands and adjacent waters. Vol. 1. Ottawa: Minister of Supply and Services. $531 \mathrm{p}$.

1981. Climatic regions of the Canadian Arctic Islands. Arctic 34:225-240.

. 1982. The climate of the Canadian Arctic Islands and adjacent waters. Vol.2. Ottawa: Minister of Supply and Services. 589 p.
OBERBAUER, S.F., and DAWSON, T.E. 1992. Water relations of Arctic vascular plants. In: Chapin, F.S., III, Jefferies, R.L., Reynolds, J.F., Shaver, G.R., Svoboda, J., and Chu, E.W., eds. Arctic ecosystems in a changing climate-An ecophysiological perspective. San Diego: Academic Press. 259-280.

PALTRIDGE, G.W., and PRATT, C.M.R. 1976. Radiative processes in meteorology and climatology. Amsterdam: Elsevier. 318 p.

ROOTS, E.F. 1989. Climate change: High-latitude regions. Climatic Change 15:223-253.

ROUSE, W.R., CARLSON, D., and WEICK, E.J. 1992. Impacts of summer warming on the energy and water balance of wet tundra. Climatic Change 22:305-326.

SCHLESINGER, M.E., and MITCHELL, J.F.B. 1987. Climate model simulations of the equilibrium climatic response to increased carbon dioxide. Reviews of Geophysics 25:760-798.

SIM, V.K. 1957. Geographical aspects of weather and climate at Eureka, Northwest Territories. Geographical Bulletin 10:36-53.

VOWINCKEL, E. 1962. Cloud amount and type over the Arctic. Arctic Meteorological Research Group Publication 51. Montreal: McGill University. 63 p.

YOUNG, K.L., and LEWKOWICZ, A.G. 1990. Surface energy balance of a perennial snowbank, Melville Island, Northwest Territories, Canada. Arctic and Alpine Research 22:290-301. 